\title{
The Implementation of Tuition-Free School Policy Using Stake's Countenance Evaluation Model
}

\author{
(A Case Study at State Junior High Schools in South Tangerang)
}

\author{
Rismita \\ Universitas Persada Indonesia YAI \\ Jakarta, Indonesia \\ mita_habib@yahoo.com
}

\begin{abstract}
The objective of this study is to understand: (1) the preliminary condition of tuition-free school policy (antecedents), (2) the implementation of the tuition-free school policy (transactions), and (3) the attainment of free-tuition school policy (outcomes) in the State Junior High Schools in South Tangerang. An evaluative approach with the Stake's Countenance Evaluation Model and a qualitative method were employed in this present research. The data sources consisted of information, research site, archives, and documents. The techniques of data collection were interviews, observations, and document study. The data were analyzed based on the components and aspects of what is evaluated and the criteria of evaluation. The results showed that the implementation of free-tuition school policy at the preliminary stage, the level of implementation and the evaluation attainment were under the moderate category since there were some schools that still did illegal charges. At the transaction/process stage, the evaluation attainment was under the high category, since all aspects involved were in line with the technical guidance in the financial use and accountability of the tuition-free school policy, and the local government gave additional fund in the form of the scholarship for the poor. At the result stage, the evaluation attainment was under the moderate category.
\end{abstract}

Keywords- Free-tuition school policy, Antecedents, Transactions, and Outcomes

\section{INTRODUCTION}

The implementation of tuition-free school policy is one of the governments' policies in terms of education finance. Either micro or macro education finance should be right and fair and leads to the goal of national education. To produce a right policy on the use of tuition-free school fund, the education finance management should be adjusted to the school finance planning, the implementation of plan-based activities, the goal attainment evaluation in the use of school budget. School finance management is intended to improve the effectiveness and efficiency in the use of school finance.

The objective of tuition-free school policy made by the government to school is to solve educational problems encountered by the school-age children to prevent them from dropouts due to their inability to pay school fee. Moreover, this policy is also intended to lighten the burden in paying the education finance in the quality nine-year compulsory education program [1]. Another objective of this policy is to aid the non-personnel operational cost of the school, improve the raw participation number, realize the partiality of the
Central Government to the students whose parents are poor by freeing and aiding school charges and other charges [2].

To measure the success of the government's compulsory education program, the number of school participation, namely the Raw Participation Number and the Pure Participation Number is adopted. Raw Participation Number is an indicator to measure the absorption of school-age population at each education level, while Pure Participation number is an indicator of better absorption since, in this kind of participation, the population participation is seen from the standard age group at the education level in accordance with the standard [3]. However, on the basis of the Raw and Pure Participation Numbers, the 9-year compulsory education program is not incomplete yet, meanwhile, the 12-year compulsory education program is very urgent to implement due to the development of knowledge and technology. A very chronic problem encountered by the people is the cost of education. Quality education needs high enough cost. Cheap education is a paradigm of which the concept resides in the mind of the Indonesian people. However, it turns out that the tuition-free school policy program has not been adequate yet and not often been right on target. The parents' economic condition really determines the success of the compulsory education [4]. Another phenomenon of the tuition-free school policy is that the policy has not been able to fulfill funds needed by schools [5].

On the basis of the phenomena above, the researcher tried to make a research on the implementation of tuition-free school policy using the Stake's Countenance evaluation model in State Junior High Schools in South Tangerang city, since this city has launched a program of education city in Banten province. As a consequence, many innovations have been made in the sector of education in order to succeed the program of education city [6].

\section{METHODS}

It is an evaluation research. Benson et al state that evaluation is comprised of diverse, oftentimes conflicting, theories and practices that reflect the philosophies, ideologies, and assumptions of the time and place in which they were constructed [7]. The evaluation approach to this research is Countenance Evaluation Model developed by Stake, covering the condition before the activity happening (antecedents), after the activity taking place and influencing one another (transactions) and the results being obtained (outcomes and a 
qualitative method [8]. The data sources consisted of information, research site, archives, and document. The techniques of data collection were interviews, observations and document study. An interactive data analysis technique was employed. The criteria of evaluation employed in this present research are presented in Table 1.

TABLE I. RESEARCH EVALUATIONS

\begin{tabular}{|c|c|c|c|c|}
\hline No. & $\begin{array}{c}\text { Evaluation } \\
\text { Stage }\end{array}$ & Component & Aspects of What is Evaluated & Evaluation Criteria \\
\hline \multirow[t]{3}{*}{1.} & \multirow[t]{3}{*}{$\begin{array}{l}\text { Antecedents } \\
\text { (Preliminary } \\
\text { Condition) }\end{array}$} & $\begin{array}{l}\text { Tuition-free school } \\
\text { policy }\end{array}$ & $\begin{array}{l}\text { The objective of the policy (the } \\
\text { government, fund share, working } \\
\text { procedure and education standard }\end{array}$ & $\begin{array}{l}\text { There are some understandings of the policy and the } \\
\text { objective of the policy in the aspect of fund } \\
\text { management and distribution }\end{array}$ \\
\hline & & \multirow[t]{2}{*}{ Personnel Students } & Quantity & Adequate personnel of students exist in each school \\
\hline & & & School Quality & Superior or quality school is possessed \\
\hline \multirow[t]{4}{*}{2.} & $\begin{array}{l}\text { Transactions } \\
\text { (Process) }\end{array}$ & $\begin{array}{l}\text { Implementation of } \\
\text { tuition-free school policy }\end{array}$ & $\begin{array}{l}\text { The process of the tuition-free school } \\
\text { policy }\end{array}$ & The tuition-free school policy is implemented \\
\hline & & \multirow[t]{3}{*}{$\begin{array}{l}\text { Students' activity of } \\
\text { tuition-free school }\end{array}$} & $\begin{array}{l}\text { The process of the implementation of } \\
\text { fund distribution }\end{array}$ & The implementation of fund distribution is reached \\
\hline & & & $\begin{array}{l}\text { The process of improving the students' } \\
\text { quality }\end{array}$ & $\begin{array}{l}\text { The implementation of improving education quality is } \\
\text { reached }\end{array}$ \\
\hline & & & $\begin{array}{l}\text { The process of the inter-party } \\
\text { coordination }\end{array}$ & The inter-party coordination is reached \\
\hline \multirow[t]{2}{*}{3.} & \multirow[t]{2}{*}{$\begin{array}{l}\text { Outcomes } \\
\text { (Results) }\end{array}$} & $\begin{array}{l}\text { Result of policy } \\
\text { attainment }\end{array}$ & Changes/Revisions of the Policy & The application of the policy is reached \\
\hline & & $\begin{array}{l}\text { Result of students' } \\
\text { achievement }\end{array}$ & $\begin{array}{l}\text { The attainment of students' academic } \\
\text { achievement }\end{array}$ & The students' academic achievement is reached. \\
\hline
\end{tabular}

TABLE II. CATEGORY OF INTERPRETATION OF DATA

\begin{tabular}{|c|c|c|}
\hline $\begin{array}{c}\text { Category Level of Implementation and } \\
\text { Attainment }\end{array}$ & \multicolumn{2}{|c|}{ Descriptor } \\
\cline { 2 - 3 } & Interpretation & Grade \\
\hline High & Most/all aspects of implementation/availability are in line with the criteria & $71-100 \%$ \\
\hline Moderate & Some aspects are implemented/available in line with some criteria & $41-70 \%$ \\
\hline Low & Few aspects are implemented/available according to the criteria & $<40 \%$ \\
\hline
\end{tabular}

Source: Ref [9]

\section{RESULTS AND DISCUSSION}

The results of the analysis of the implementation of the tuition-free school policy are presented in Table III

\section{A. Preliminary Condition (antecedents)}

The term of tuition-free school policy stated in the Regulation of the Minister of Education and Culture of the Republic of Indonesia No. 80 Year of 2015 is the government program which is basically intended to provide the funding of nonpersonnel operation cost for a primary education unit as the implementer of the compulsory learning program.

The implementation of the preliminary condition (antecedents) in this evaluation research is based on two components. The first component is that the policy on the application of the tuition-free school is intended to lighten up the burden of the people in financing education for the attainment of quality 9-year compulsory program, and play roles in accelerating the accomplishment of Minimal Service Standard in education units that have not fulfilled the Minimal Service Standard and that of Education National Standard in those that have fulfilled the Minimal Service Standard.

Specifically, the tuition-free school policy program aims at (1) freeing charges for all students at state elementary and junior high schools in terms of the operational cost of education units, (2) freeing any charges for students from poor families, either in state or private education unit, and (3) lengthening the burden of education unit operation cost for students in private education unit.
On the basis of the objective of the tuition-free school policy above, it is known that in the organization of education in some state schools in South Tangerang city, some illegal charges were found. The parents were asked to pay some items, from the selection of school entrance, buying textbooks, student's work sheets to comparative study [10]

The second component is that the quantity-based student personnel is all elementary and junior high schools, either state of private in the whole province in Indonesia, especially in Banten province had possessed the Number of National School and had been enlisted in the Education Data System. In this present research, the number of State Junior High Schools in South Tangerang city was 21 . The amount of fund for the tuition-free school policy was Rp.1.000.000; for each student/year. But based on the consideration that some fixed cost components, from the cost for education unit operation which does not depend on the number of students, the government applied a special for an education unit with the number of students of less than 60 students [11].

\section{B. Process (Transaction)}

At the process stage, in the first component, the implementation of the tuition-free school policy is that before the fund is disbursed to schools, the Education Office of Banten province held training and socialization of the Regulation of the Minister of Education and Culture No. 161 Year of 2014 on the technical guide in the use and financial accountability of fund for the tuition-free school policy. This socialization was intended to create a synergy of the tuition- 
free school program to make the program right on target and it was also addressed for the tuition-free school policy team of South Tangerang city, headmasters, schools treasurers, operators of the Education Main Data, Integrated Service Units of Education Office, supervisors and Education Boards.

In the second component namely the activities of the students of tuition-free school based on the process of the implementation of fund distribution, all education units that have been included in the Elementary and Secondary Education Main Data are obliged to receive the fund of tuitionfree policy. Meanwhile, on the basis of the process of improving the students' quality, the fund of tuition-free school policy is an important factor to improve the access to the quality 9 years compulsory program and to assure that no poor students who would drop out. Another fund was given by the government of South Tangerang city through the Education Office is scholarship special for poor students intended to prosper them [12]. The process of coordination among the interested parties is that the government of Banten province has made various policies and strategies which are elaborated into programs and activities conducted under the coordination with the Local Government through the Education Office and with headmasters.

\section{Results (Outcomes)}

From the implementation of the tuition-free school policy at the third stage, in the first component, it is shown that the results of the attainment of tuition-free school policy have been in line with technical guide in the use and the financial accountability of the fund of tuition-free school policy on the basis of the school program made in a three-month budget, focused on the development of: (1) the graduates' competence, (2) the content standard, (3) the process standard, (4) the teachers and educational staffs, (5) infrastructures and facility, (6) the standard of management, (7) the standard of financing and the grade system and the implementation of it. In this case, the local government also checked the use of the fund for tuition-free school policy. Supervision was also made through the monitoring and evaluation instruments to schools, and questionnaires as the monitoring instrument of the program implementation were given to the parents and the headmasters. To know the effectiveness of the fund for tuition-free school policy, each school should present its financial statement. Although the local government through its Education Office has made the monitoring and evaluation, schools which obliged their students to buy textbooks and students' worksheet and to pay other costs were still found, whereas all fund details had been included in the use of the school budget. This really burdened the parents.

In the second component, the results of either academic or non academic achievement of the students of State Junior High School in South Tangerang city were among others as the finalist of the National Science Olympiad in Singapore International Mathematic Challenge. Other students' academic achievements in line with the vision and the missions of each school were among other the realization of graduates with good characters, high competences and good religious attitudes. On the basis of the achievements attained by the students at schools, the quality of the education and of the human resources may be improved.

TABLE III. RESEARCH RESULTS

\begin{tabular}{|c|c|c|c|c|c|}
\hline No. & $\begin{array}{c}\text { Evaluation } \\
\text { Stage }\end{array}$ & Component & Aspects of What is Evaluated & Evaluation Criteria & Research Result \\
\hline \multirow[t]{3}{*}{1.} & \multirow[t]{3}{*}{$\begin{array}{l}\text { Antecedents } \\
\text { (Preliminary } \\
\text { Condition) }\end{array}$} & $\begin{array}{l}\text { Tuition-free } \\
\text { school policy }\end{array}$ & $\begin{array}{l}\text { The objective of the policy (the } \\
\text { government, fund share, } \\
\text { working procedure and } \\
\text { education standard }\end{array}$ & $\begin{array}{l}\text { There are some understandings of } \\
\text { the policy and the objective of the } \\
\text { policy in the aspect of fund } \\
\text { management and distribution }\end{array}$ & $\begin{array}{l}\text { It is in line with the specific objective of } \\
\text { the fund of tuition-free school policy. } \\
\text { But some illegal charges were still } \\
\text { found }\end{array}$ \\
\hline & & $\begin{array}{l}\text { Personnel } \\
\text { Students }\end{array}$ & Quantity & $\begin{array}{l}\text { Adequate personnel of students } \\
\text { exist in each school }\end{array}$ & $\begin{array}{l}\text { All schools possessing the Number of } \\
\text { the National School } \\
\text { was listed in the Education Main Data }\end{array}$ \\
\hline & & & School Quality & $\begin{array}{l}\text { Superior or quality school is } \\
\text { possessed }\end{array}$ & $\begin{array}{l}\text { It may improve the development in the } \\
\text { field of education }\end{array}$ \\
\hline \multirow[t]{4}{*}{2.} & \multirow[t]{4}{*}{$\begin{array}{l}\text { Transactions } \\
\text { (Process) }\end{array}$} & $\begin{array}{l}\text { Implementation } \\
\text { of tuition-free } \\
\text { school policy }\end{array}$ & $\begin{array}{l}\text { The process of the tuition-free } \\
\text { school policy }\end{array}$ & $\begin{array}{l}\text { The tuition-free school policy is } \\
\text { implemented }\end{array}$ & $\begin{array}{l}\text { It is in line with the Regulation of the } \\
\text { Minister of Education and Culture No. } \\
161 \text { year of } 2014\end{array}$ \\
\hline & & \multirow{3}{*}{$\begin{array}{l}\text { Students' } \\
\text { activity of } \\
\text { tuition-free } \\
\text { school }\end{array}$} & $\begin{array}{l}\text { The process of the } \\
\text { implementation of fund } \\
\text { distribution }\end{array}$ & $\begin{array}{l}\text { The implementation of fund } \\
\text { distribution is reached }\end{array}$ & $\begin{array}{l}\text { All education units had been listed in the } \\
\text { Primary and Secondary Main Data }\end{array}$ \\
\hline & & & $\begin{array}{l}\text { The process of improving the } \\
\text { students' quality }\end{array}$ & $\begin{array}{l}\text { The implementation of improving } \\
\text { education quality is reached }\end{array}$ & $\begin{array}{l}\text { It may improve the access to quality } \\
\text { nine-year compulsory education }\end{array}$ \\
\hline & & & $\begin{array}{l}\text { The process of the inter-party } \\
\text { coordination }\end{array}$ & $\begin{array}{l}\text { The inter-party coordination is } \\
\text { reached }\end{array}$ & $\begin{array}{l}\text { The coordination was made among the } \\
\text { local government, the Education Office } \\
\text { and headmasters }\end{array}$ \\
\hline \multirow[t]{2}{*}{3.} & \multirow[t]{2}{*}{$\begin{array}{l}\text { Outcomes } \\
\text { (Results) }\end{array}$} & $\begin{array}{l}\text { Result of policy } \\
\text { attainment }\end{array}$ & $\begin{array}{l}\text { Changes/Revisions of the } \\
\text { Policy }\end{array}$ & $\begin{array}{l}\text { The application of the policy is } \\
\text { reached }\end{array}$ & $\begin{array}{l}\text { It is in line with the technical guide in } \\
\text { using fund but the parents were still } \\
\text { burdened with some cost }\end{array}$ \\
\hline & & $\begin{array}{l}\text { Result of } \\
\text { students' } \\
\text { achievement }\end{array}$ & $\begin{array}{l}\text { The attainment of students' } \\
\text { academic achievement }\end{array}$ & $\begin{array}{l}\text { The students' academic } \\
\text { achievement is reached. }\end{array}$ & $\begin{array}{l}\text { Graduates with good characters, high } \\
\text { competence and religious attitudes were } \\
\text { produced }\end{array}$ \\
\hline
\end{tabular}




\section{CONCLUSION}

In the implementation of the tuition-free school policy at the preliminary condition, the levels of implementation and of the evaluation attainment are under the moderate category, due to the fact that some schools still make illegal charges. At the process stage, the levels of implementation and of the evaluation attainment are under the high category, because all aspects included have been in line with the technical guide and the financial accountability of fund for the tuition-free school policy, and the local government has given additional funds in the form of the scholarship special for the poor students. At the result stage, the levels of implementation and the evaluation attainment are included into the moderate category, because there were schools that charged fees that merely burdened the parents, whereas, in the tuition-free school policy program, no additional charges should be made.

\section{REFERENCES}

[1] Undang-Undang Nomor 20 Tahun 2003 tentang Sistem Pendidikan Nasional

[2] Republika. "Kementerian Pendidikan dan Kebudayaan Berlakukan Pembelanjaan BOS Nontunai,"Republika Online. http://www.republika.co.id/kemendikbud-berlakukan-pembelanjaan-bosnontunai. (diakses 17 Maret 2017)

[3] BPPNDIK. "Penilaian Pelaksanaan Program Wajib Belajar Pendidikan Dasar," BPPNDIK Online. http://bppndik.tripod.com/wajar.html. (diakses 18 April 2017)

[4] Matra Pendidikan. "Quo Vadis Program Wajib Belajar," Matra Pendidikan Online.http://www.matrapendidikan.com/quo-vadisprogram-wajib-belajar. (diakses 10 Maret 2017)

[5] Republika. "Dana BOS Dinilai Belum Penuhi Kebutuhan Sekolah," Republika Online.http://nasional.republika.co.id/dana-bos-dinilai-belumpenuhi-kebutuhan-sekolah. (diakses 18 Maret 2017)

[6] Dewi, Roosnila Aris. "Subsidi BOS dan Implementasinya pada Jenjang SMP di Kota Tangerang Selatan,”. Jakarta: Tesis FISIP UI. 2010.

[7] Benson, Michelle Hinn, dan Claire Llyod. (2001). "Advances In Program Evaluation,". Elsevier Science Ltd.

[8] R. E. Stake. "Program Evaluation, Particularly Responsive Evaluation," In Evaluation Models, Springer, 1983, pp.287-310.

[9] Djaali dan Pudji Muljono. (2008). "Pengukuran Dalam Bidang Pendidikan,". Jakarta: Grasindo.

[10] Lembaga Tangerang Public Transparency Watch (TRUTH). Pungutan Liar Terjadi di Sekolah Negeri di Tangerang Selatan,". Kompas Online. http://megapolitan.kompas.com/pungutan.liar.terjadi.di.sekolah.negeri.di .tangerang.selatan. (diakses 22 April 2017)

[11] Republika. "Dana BOS Banten Capai Rp. 1,3 T,". Republika Online. http://www.republika.co.id/dana-bos-banten-capai-rp-1,3-t. (diakses 18 Maret 2017)

[12] Pemda Tangsel. "Dinas Pendidikan Tangsel Sejahterakan Siswa Miskin,". Tangerangnews Online. http://tangerangnews.com/DinasPendidikan-tangsel-Sejahterakan-Siswa-Miskin. (diakses 21 April 2017) 